\title{
EXPERIMENTAL STUDY OF THE NEUROTOXIC EFFECTS OF PHOTODYNAMIC THERAPY ON THE SPINAL CORD
}

\author{
ESTUDO EXPERIMENTAL DOS EFEITOS NEUROTÓXICOS DA TERAPIA FOTODINÂMICA \\ NA MEDULA ESPINHAL
}

\author{
ESTUDIO EXPERIMENTAL DE LOS EFECTOS NEUROTÓXICOS DE LA TERAPIA \\ FOTODINÁMICA EN LA MÉDULA ESPINAL
}

\begin{abstract}
Herton Rodrigo Tavares Costa, ${ }^{1}$ Elaine Aparecida Del Bel Belluz Guimarães, ${ }^{2}$ Antônio Claudio Tedesco, ${ }^{3}$ Fernando lucas Primo, ${ }^{3}$ Céla Aparecida da Silva, ${ }^{4}$ luciana Almeida lopes, ${ }^{5}$ Lisinéia Maria Zanardi, ${ }^{5}$ Helton luiz Aparecido Defino ${ }^{1}$
1. University of São Paulo, Faculty of Medicine of Ribeirão Preto, Department of Biomechanics, Medicine and Rehabilitation of the Locomotor Apparatus, Ribeirão Preto, SP, Brazil. 2. University of São Paulo, Dental School of Ribeirão Preto, Department of Morphology, Stomatology and Physiology, Ribeirão Preto, SP, Brazil.
3. University of São Paulo, Faculty of Philosophy, Sciences and Letters of Ribeirão Preto, Ribeirão Preto, SP, Brazil.
4. University of São Paulo, Dental School of Ribeirão Preto, Department of Morphology, Stomatology and Physiology, Laboratory of Molecular Neurophysiology, Ribeirão Preto, SP, Brazil.
5. Research and Education Center for Phototherapy in Health Science (NUPEN), São Carlos, SP, Brazil.

\begin{abstract}
Objective: To evaluate the effects of photodynamic therapy (PDT) on the dura mater using the photosensitizers aluminum chloride phthalocyanine and methylene blue in in vivo assays. Methods: Fifty-six male Wistar rats were divided into two groups; one submitted to PDT and the other submitted to the photosensitizers without their photoactivation (control). The photosensitizers were applied to the dura mater after laminectomy at the T10 level. The methods used for assessment were the Basso, Beattie and Bresnahan (BBB) functional evaluation scale and study of the dura mater by light microscopy. Results: No changes in motor activity were observed in the animals submitted to PDT compared to control. Histological and pathological evaluation did not show any differences between the group exposed to activated photosensitizers and the control group with regard to the inflammatory process and tissue necrosis. Conclusion: The joint use of PDT with the photosensitizing pharmaceuticals aluminum chloride phthalocyanine and methylene blue did not induce any clinical neurotoxic effects or histological changes in the dura mater of the animals studied. Nível de evidência V; Opinião de Especialista.
\end{abstract}

Keywords: Photochemotherapy; Dura Mater; Methylene Blue; Laser.

\section{RESUMO}

Objetivo: Avaliar os efeitos da terapia fotodinâmica (PDT) na dura-máter usando os fotossensibilizadores cloreto de alumínio ftalocianina e azul de metileno em ensaios in vivo. Métodos: Cinquenta e seis ratos Wistar machos divididos em dois grupos; um submetido à PDT e o outro submetido aos fotossensibilizadores sem a fotoativação (controle). Os fotossensibilizadores foram aplicados sobre a dura-máter depois de laminectomia no nível T10. Os métodos de avaliação usados foram a escala de avaliação funcional de Basso, Beattie e Bresnahan (BBB) e o estudo da dura-máter por microscopia óptica. Resultados: Não foram observadas alterações da atividade motora dos animais submetidos à PDT com relação ao grupo controle. A avaliação histológica e histopatológica não mostrou diferenças entre o grupo exposto aos fotossensibilizadores ativados e o grupo controle, com relação ao processo inflamatório e à necrose tecidual. Conclusões: O uso conjunto de PDT e os fármacos fotossensibilizantes cloreto de alumínio ftalocianina e azul de metileno não induziu efeitos neurotóxicos clínicos e/ou alterações histológicas sobre a dura-máter dos animais estudados. Level de evidence V; Expert Opnion.

Descritores: Fotoquimioterapia; Dura-Máter; Azul de Metileno; Laser.

\section{RESUMEN}

Objetivo: Evaluar los efectos de la terapia fotodinámica (PDT) en la duramadre utilizando los fotosensibilizadores de ftalocianina de aluminio clorada y azul de metileno en ensayos in vivo. Métodos: Cincuenta y seis ratas Wistar machos se dividieron en 2 grupos; uno fue sometido a PDT y el otro sometido a fotosensibilizadores sin fotoactivación (control). Los fotosensibilizadores se aplicaron a la duramadre después de la laminectomía en el nivel T10. Los métodos de evaluación utilizados fueron la escala de evaluación funcional de Basso, Beattie y Bresnahan (BBB) y el estudio de la duramadre mediante microscopía óptica. Resultados: No hubo cambios en la actividad motora de los animales sometidos a PDT en relación con el grupo de control. La evaluación histológica e histopatológica no mostró diferencias entre el grupo expuesto a fotosensibilizadores activados y el grupo de control con respecto al proceso inflamatorio y la necrosis tisular. Conclusiones: El uso conjunto de PDT con las sustancias fotosensibilizadores ftalocianina de aluminio clorada y azul de metileno no indujo efectos neurotóxicos clínicos o cambios histológicos en la duramadre de los animales estudiados. Nivel de evidencia V; Opinión del Especialista.

Descriptores: Fotoquimioterapia; Duramadre; Azul de Metileno; Rayos Láser. 


\section{INTRODUCTION}

Photodynamic therapy (PDT) is a promising treatment for cancer and non-oncological diseases..$^{1-4}$ It combines a photosensitizer drug (PS, organic dye) with visible light irradiation in the range of the electromagnetic spectrum of appropriate wavelength, and oxygen, each of which alone is harmless. The photodynamic effect produces reactive oxygen species (ROS), which function as lethal cytotoxic agents that inactivate tumor cells, bacteria and other living species. Interestingly, the photosensitizer drug is preferentially absorbed by the desired tissue, and the light irradiation is limited to a specific region. This confers dual selectivity to the PDT technique. Hence, PDT allows for the selective activation of target tissue while healthy tissue remains intact. ${ }^{5-7}$ The mechanism of cell death could be by classical necrosis or apoptosis. ${ }^{8,9}$ Hematoporphyrins were the first generation of PS applied in clinical PDT procedures. With the aim of improving PDT efficacy by increasing diseased tissue penetration, researchers have developed the second generation of PS drugs, phthalocyanine being the main representative of this generation. ${ }^{10,11}$ The preclinical application of such drugs has seen a significant rise in many fields in the last decade.

Aluminum chloride phthalocyanine (AICIPC) is a chemically stable second-generation photosensitizer that displays adequate photophysical properties (such as high triplet quantum yields and long triplet lifetimes) for PDT. ${ }^{12}$ Methylene blue (MB), a generation of AICIPC that is also adsorbed in the visible range of the spectrum, also leads to a biological response in the tissues of different species. Even though AICIPC has high molecular weight, its hydrophobic nature facilitates its interaction with lipid bilayers. AICIPC-PDT has been successfully used in cancer models, affording a relevant safety margin in medical trials. ${ }^{13-15}$ The procedures described above could be used for topical or systemic application, with target specificity as desired.

The advantage of PDT over other clinical procedures is that it has no toxic side effects and it can be applied repeatedly, over a short period of time, with low risk to the patient. ${ }^{2}$ PDT has also been frequently used for photodiagnostic purposes, since most of the PS used have the ability to absorb light and to produce active species (ROS) or emit light as fluorescent probes for diagnosis. ${ }^{16}$

Given that PDT has become a first choice treatment for many diseases, and in view of the absence of data showing the effect of PDT on the nervous system, the objective of this study was to analyze this behavior and to elect PDT for application as a therapeutic treatment for spinal diseases. It therefore assesses, experimentally, the neurotoxic effects of PDT and the photosensitizers AICIPC and MB on the spinal cord and dura mater of rats, investigating any changes in motor functions of the nervous system.

\section{METHODS}

The study was approved by the Ethics Committee for Animal Experimentation of the Faculty of Medicine of Ribeirão Preto - USP (protocol no. 005/2014). Fifty-six male Wistar rats weighing 250-300 $\mathrm{g}$ were divided into 2 experimental groups. In Group A (intervention), the light source used was low intensity laser (Model: Therapy XT, DMC - São Carlos, Sao Paulo, Brazil) with 660 nm wavelength and $100 \mathrm{~mW}$ maximum optical power, delivered through a fiber 600 $\mu \mathrm{m}$ diameter with a distance gauge providing a $2.35 \mathrm{~mm}$ diameter spot size. The laser was applied in continuous mode $(\mathrm{CW})$ in direct contact with the dura mater for 90 seconds to activate the photosensitizers AICIPC and MB. In Group B (control) we used only the photoactive agents in their basic formulations directly applied to the dura mater. The groups were divided into 4 subgroups of 7 animals each, according to the substance used: physiological saline, $56 \mu \mathrm{M}$ AICIPC solution, $10 \% \mathrm{MB}$ solution ( $\mathrm{v} / \mathrm{v})$, and a solution containing both agents: $56 \mu \mathrm{M}$ AICIPC $+10 \% \mathrm{MB} v / \mathrm{v}$.

The animals were anesthetized with a mixture of $20 \mathrm{mg} / \mathrm{ml} \mathrm{xy}$ lazine $(0.7 \mathrm{ml} / 100 \mathrm{~g})$ and $50 \mathrm{mg} / \mathrm{ml}$ ketamine $(1 \mathrm{ml} / 100 \mathrm{~g})$. Laminectomy was performed by the dorsal approach to the spine at the T10 level, and the dura mater was exposed in each subgroup. One $\mathrm{ml}$ of physiological saline or $0.3 \mathrm{ml}$ of the photosensitizers
(AICIPC, MB and AICIPC $+\mathrm{MB}$ ) was then applied directly to the dura mater in both groups. A mean time of 5 minutes was allowed to elapse between groups. After the procedure, the surgical wound was sutured plane by plane, and the animals were kept in $20 \times 40$ $\mathrm{cm}$ polypropylene cages (type $\mathrm{C}$ ), with 4 animals to a cage.

To test whether new therapeutic strategies can significantly induce a biological response in the dura mater, we investigated the photodynamic activity of AICIPC and/or MB loaded into an oil/water nanoemulsion (AICIPC/NE, MB/NE and $\mathrm{AICIPC}+\mathrm{MB} / \mathrm{NE}$ ) on dura mater tissue. The choice of active agent/NE was based on the fact that AICIPC and ME are hydrophobic and hydrophilic photosensitizer drugs, ${ }^{12}$ respectively, while the oil/water NE can potentially deliver both poorly and efficient water-soluble drugs to the target site in a synergist action. ${ }^{17}$ Both combinations have been used in a Hydrogel formulation for better application to the target tissue. The stock solution of both dyes was prepared in dimethylsufoxide (DMSO) at a maximum concentration of $0.1 \mathrm{~mol} / \mathrm{L}$, prepared according to the classical NE procedures previously described. ${ }^{18,19}$

The following methods were used for assessment: functional evaluation using the Basso, Beattie and Bresnahan (BBB) ${ }^{20}$ scale, histological and histopathological investigation of the dura mater by light microscopy, and hematoxylin-eosin staining.

Neurological examination was performed preoperatively, after recovery from anesthesia and 7 days after the procedure, when the animals were sacrificed and slides were obtained. The BBB scale uses behavioral parameters related to the motor function of the animal and attributes scores according to each function. A score of 0 corresponds to absence of movements and a score of 21 to normal locomotor activity. (Table 1)

Histology was performed using dura mater and spinal cord slides obtained after sacrificing the animals. Six- $\mu \mathrm{m}$ thick histological sections were obtained with a Leica RM 2065 model microtome and stained with hematoxylin-eosin according to the classical procedure described by Behmer et al. ${ }^{21}$

Slide images were recorded using a Carl Zeiss Axiovert 40-CFL inverted light microscope coupled to a high-resolution Axio-Cam MRC digital camera calibrated for image capture based on phase contrast, plastic (3D) and fluorescence emission. The software program Axiovision LE V.4.8.2.0 was used to quantitate the areas of the labeled regions according to the variables of the experiment, with automatic calculation and conversion to pixels. Histological analysis enabled us to assess the degree of action in each photoactivation and/or treatment group.

The slides of groups A and B were analyzed by counting pixels in the regions stained with hematoxylin-eosin. (Figure 1) Hematoxylin stains the cell nuclei, while eosin stains the extracellular matrix for the assessment of the integrity of nuclei and cells, respectively. Thus, we compared the integrity of the meninges and the neurons (number of nuclei and cytoplasms) and determined the presence or absence of inflammatory cells in the various groups by counting the pixels of each image in relation to the control group and to a standard healthy model.

Histopathological analysis was performed by a pathologist of the Pathology Group of the University Hospital, Faculty of Medicine of Ribeirão Preto, USP, Ribeirão Preto (SP) Brazil, who determined the presence of dead cells due to necrosis or the production of inflammatory cells. The slides were examined under an Olympus BX40 light microscope with oil objectives at 400X.

The degree of inflammatory infiltrate was quantitated as follows: + (less than 20 inflammatory cells /400X magnification field); ++ (21 to 50 cells/400X magnification field); +++ (more than 50 cell/ 400X magnification field).

\section{Statistical Analysis}

The data were analyzed statistically by one-way analysis of variance (ANOVA) between the treatments performed in the subgroups. The Tukey post-test was applied, and the level of significance was set at $5 \%(p<0.05)$. The analysis was carried out using the software program Axiovision LE V.4.8.2.0 (Zeiss). 
Table 1. Results of the Basso, Beattie and Bresnahan (BBB) scale for locomotor assessment applied to the animals under study.

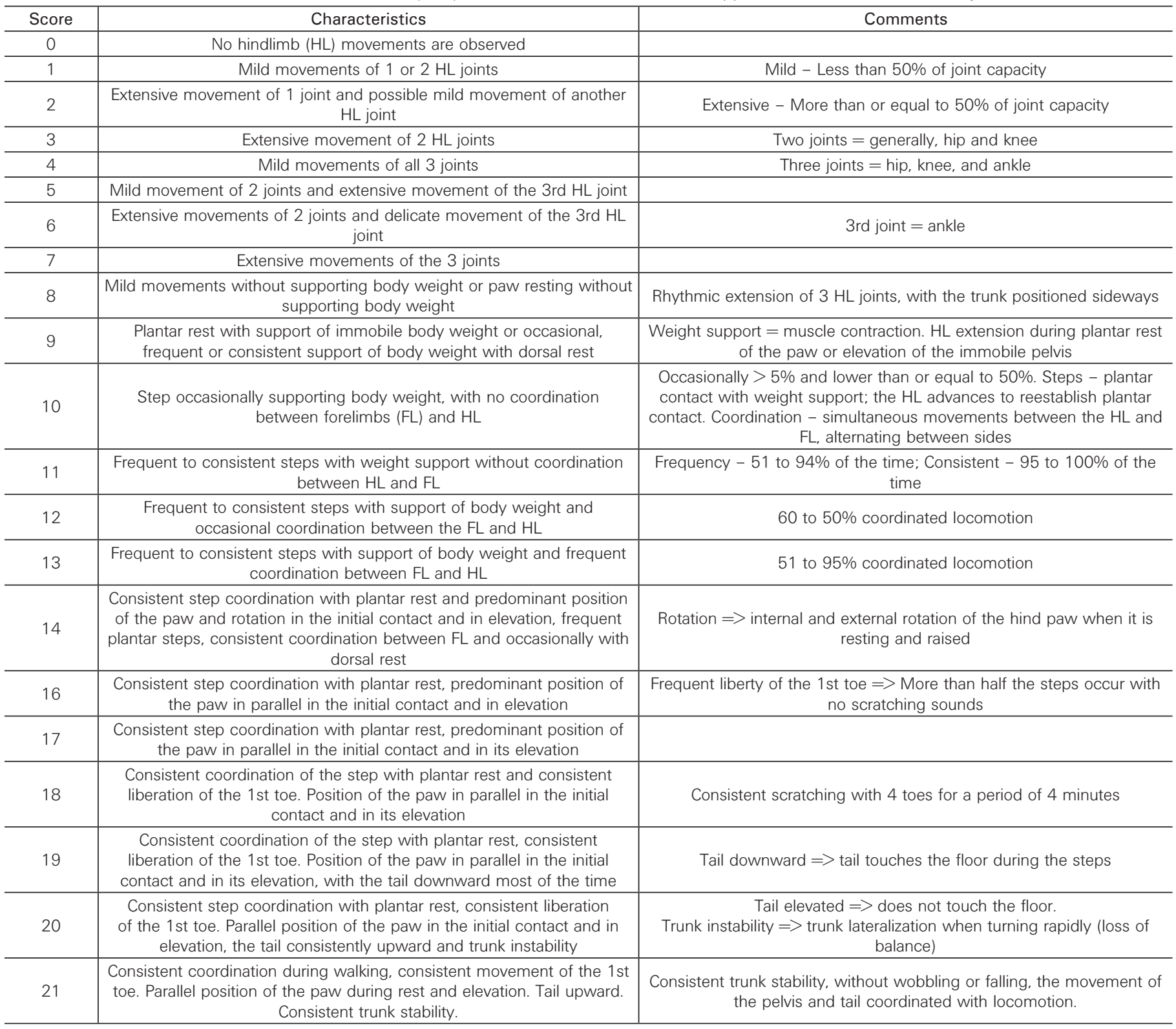


Figure 1. Histological sections stained with Hematoxylin (A) and Eosin (B) after incubation of different samples: $P S=$ physiological solution; MB = methylene blue; $\mathrm{AICIPC}=$ aluminum chloride phthalocyanine; $\mathrm{MB}+\mathrm{AICIPC}=$ methylene blue + aluminum chloride phthalocyanine. 


\section{RESULTS}

The effects of PDT on the dura mater after T10 laminectomy were analyzed according to the following criteria: a) neurological signs and symptoms, b) quantity of necrotic tissue, and c) quantity of inflammatory cells, comparing the experimental group to the control group. Thus, it was possible to observe the effect of visible laser at $660 \mathrm{~nm}$ on the photoactive agents studied in their specific formulations, which guaranteed their best interaction in an isolated and joint manner when applied to the dura mater with and without photoactivation.

All animals were examined. None of them showed neurological deficits. All of them reached 21 points on the BBB scale after recovery from anesthesia and on the seventh postoperative day (168 hours), as shown in Table 1.

The slides of groups A and B were analyzed by pixel count after staining with hematoxylin and eosin (Figure 1), assessing and comparing the integrity of cell nuclei and cytoplasm between the experimental and control groups. Thus, it was possible to assess the integrity of the dura mater, as well as the behavior of the neurons in the various groups.

Group A was divided into subgroups treated with saline solution, $\mathrm{AICIPC}, \mathrm{MB}$ and $\mathrm{MB}+\mathrm{AICIPC}$, plus treatment with visible laser at 660 $\mathrm{nm}$ frequency. This enabled us to analyze the individual neurotoxicity of each substance, as well as the combined action of both after laser treatment, and to compare the results to those of the control group (saline solution + laser). As anticipated, no significant difference $(p<0.005)$ was observed between groups, as shown in. Figures 2 and 3

Group B (with no light treatment) was also divided into subgroups as Group A. The individual and combined neurotoxicity of the substances were analyzed without the influence of laser and compared to the control (saline solution). No significant difference $(p<0.005)$ was detected, as shown in. Figures 4 and 5

Histopathological analysis did not reveal tissue necrosis, and an inflammatory infiltrate with the presence of lymphocytes was detected on the following slides:

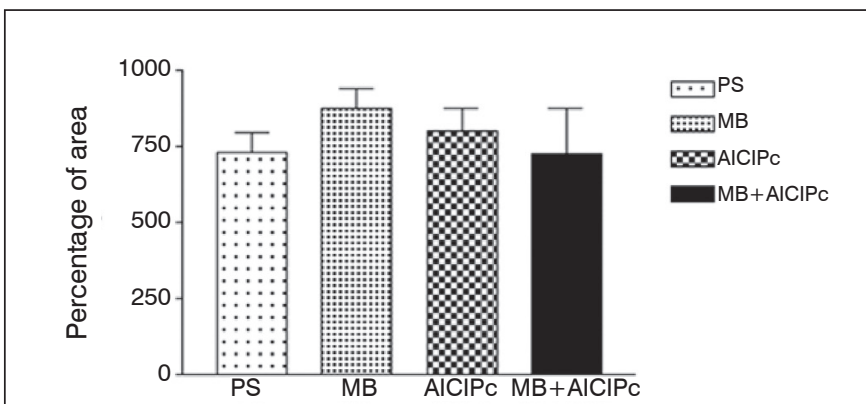

$\mathrm{PS}=$ physiological solution; $\mathrm{MB}=$ methylene blue; $\mathrm{AICIPC}=$ aluminum chloride phthalocyanine; $\mathrm{MB}+\mathrm{AICIPC}=$ methylene blue + aluminum chloride phthalocyanine. Ordinate: Percentage of area

Figure 2. Comparison of percent area with histological hematoxylin staining after incubation of different samples and laser application.



$\mathrm{PS}=$ physiological solution; $\mathrm{MB}=$ methylene blue; $\mathrm{AICIPC}=$ aluminum chloride phthalocyanine; $\mathrm{MB}+\mathrm{AICIPC}=$ methylene blue + aluminum chloride phthalocyanine. Ordinate: Percentage of area.

Figure 3. Comparison of percent area with histological eosin staining in biopsies after incubation of different samples and laser application.

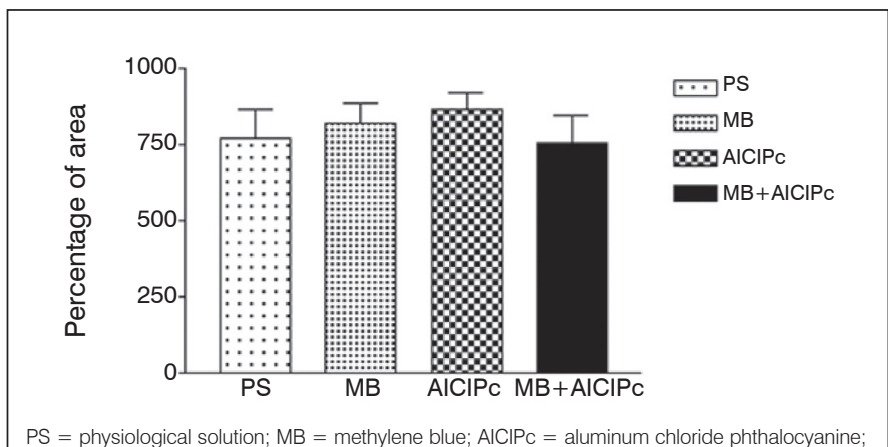
$\mathrm{MB}+\mathrm{AICIPC}=$ methylene blue + aluminum chloride phthalocyanine. Ordinate: Percentage of area.

Figure 4. Comparison of percent histological hematoxylin labeling in biopsies after incubation with different samples.

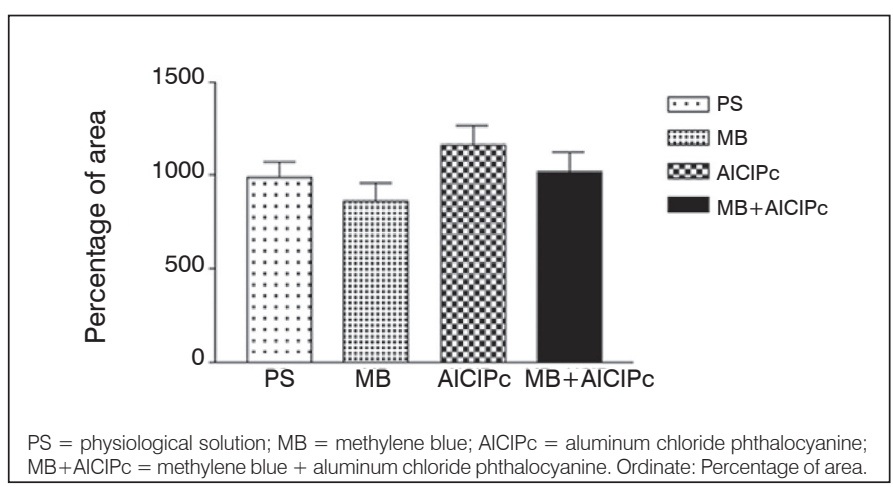

Figure 5. Comparison of percent area of histological eosin staining in biopsies after incubation with different samples.

- 1 animal treated with laser + AICIPc: inflammation $+/ 3+$ (single focus). - 1 animal treated with MB + AICIPC: inflammation +/3+ (single focus). - 1 animal treated with $\mathrm{MB}+\mathrm{AICIPC}+$ laser: inflammation: $++/ 3+$ (single focus).

- 1 animal treated with MB + laser: inflammation + (single focus).

- Neurological, structural and inflammatory analysis was therefore performed, comparing the experimental groups with each other and with the control, as well as the various subgroups.

\section{DISCUSSION}

The functional, histological, pixel count and histopathological analyses and quantitation of the processes for hematoxylin and eosin staining showed that PDT with the photosensitizer pharmaceuticals (PPS) in question (AICIPc and MB) had no neurotoxic effects when applied directly to the dura mater. They also showed no motor changes, cell death or apoptosis, or significant inflammatory activity. It should be pointed out that both agents used in our study have a rich history of use in PDT, although this was the first time they had been used in combination for the treatment of spinal diseases. In addition, each active agent has different characteristics, one of them being highly hydrophilic and the other highly hydrophobic, so that when properly nanovehiculated, they do not give rise to a new and system of photoactive pharmaceuticals, enabling their synergistic action on the photoactivation process, since their location in the tissue is differentiated.

Data on the clinical applications of PDT are limited within this biological context and most of the previous studies using PDT have assessed its proven antineoplastic and antiviral actions. Also, some clinical antibacterial studies have been reported. ${ }^{22}$ Numerous clinical trials were reported in the 1970s for the treatment of herpes simplex with photoactivation in recurrent lesions. ${ }^{23,24}$

A $1 \%$ neutral red solution was applied topically, followed by exposure to a $40 \mathrm{~W}$ incandescent tungsten lamp for 15 minutes. The treatments, however, were interrupted due to the low efficacy and 
possible carcinogenicity of the method. Indeed, it was not known, at that time, that it would be necessary to use monochromatic lights to ensure greater absorption by the photoactive agents, or that these lights would be able to activate the photochemical and photobiological pathways of the cell response, with complete safety and avoiding side effects. In recent studies, PDT using photosensitizers such as 5-aminolevulinic acid (ALA), hematoporphyrin derivatives (HPD, Photofrin), talaporfin sodium, or meta-tetra(hydroxyphenyl)chlorin (mTHPC) has proven to be a positive adjunctive treatment for skin cancer and brain tumors in the clinical setting. Therefore, the theranostic properties of PDT could improve control of the local action of reactive species produced during the classical treatment. ${ }^{1,5,25,26}$ Most of the work done with 5-ALA has been conducted in clinical trials in many countries around the world, particularly Brazil, in studies conducted at the University of Sao Paulo, Ribeirão Preto, focusing on neoplastic diseases, with excellent results. ALA has also proved to be efficient for the treatment of molluscum contagiosum (caused by poxvirus, HPV), the virus that causes vesicular stomatitis. ${ }^{27}$ Abdel-Hady et al. ${ }^{28}$ used topical ALA-PDT to treat neoplastic vulvar lesions, but observed a short-term response in only one third of cases.

The authors consider AICIPC to be a stable second generation photosensitizer drug with optimal wavelengths in most of the electromagnetic spectrum $(610-660 \mathrm{~nm}) .{ }^{12}$ This photosensitizer has previously induced apoptotic cell death in glioma cells. ${ }^{29}$ AICIPC is a chemically stable second-generation photosensitizer that displays adequate photophysical properties (such as high triplet quantum yields and long triplet lifetimes) for PDT. ${ }^{12}$ Even though AICIPC has high molecular weight, its hydrophobic nature facilitates its interaction with lipid bilayers. AICIPC-PDT has been successfully used in cancer models, affording a relevant safety margin in medical trials. ${ }^{13-15}$ The absorption and emission of light at long wavelength PS and the nanodrug delivery system enable deeper lesions to be reached. ${ }^{8}$

The chemical structure contains a variety of metal ions which are responsible for the particular properties of each molecule. Aluminum (III) and zinc (II) are two metal ions used to improve phototoxicity. A further advantage of phthalocyanin-based dyes is that they can be selectively accumulated inside the cell and eliminated in a much more efficient manner from the target tissue, with almost complete absence of the fluorescence observed in the cells 24 hours after administration of the pharmaceutical agent. ${ }^{28,30}$

Today, it is well recognized that the development of a new system of drugs that photosensitize classic carriers can increase the advantages of PDT, as recently demonstrated in the literature. Among the available systems, liposomes are probably the simplest and the most biocompatible, and are therefore proposed to transport and provide photosensitizers. This strategy was based on the premise that liposomes are preferentially absorbed by a local tumor and by the surrounding vessels. ${ }^{31,32}$ Within this context, the cited studies have shown the effects of a liposomal AICIPc used in the formulation of PDT in oral cancer cells. These results demonstrate that PDT and AICIPC, with their high cytotoxicity to oral cancer cell cultures, significantly reduce cell proliferation, and also show the different characteristics of necrosis in treated cells. Taken together, these data suggest good perspectives for the clinical use of PDT, MB and AICIPC. ${ }^{33,34}$

Functional assessment with the BBB scale revealed that no neurological damage occurred in any animal. These results indicate that the application of laser and photosensitizers did not induce functional changes in the meninges or neurons. PDT has been used for the treatment of spinal lesions with AICIPc excited by infrared light, reducing the density of glial cells in the epicenter of the lesion, and thus inhibiting the formation of a glial scar and reducing the chance of neurological deficit. ${ }^{35}$

In the present study, histological analysis by pixel count and histopathological analysis of the slides revealed no significant structural damage to the dura mater or the neurons. The pixel count showed that the number of cell nuclei and cells (intact cytoplasm membranes) was similar in the subgroups when the photosensitizers were applied separately or in combination (Figures 2, 3, 4 and 5) and no cell death or apoptosis was observed. Microscopic examination did not reveal significant inflammatory activity. Only a small focal inflammatory lymphocyte infiltrate was detected on 4 slides, as described in the histopathological analysis section. Lambrechts et al. ${ }^{36}$ reported that PDT using cationic porphyrin inactivated Candida albicans by damaging the cytoplasm membrane. Electron microscopy images clearly showed that the damage produced occurred from the outer to the inner layers of the cytoplasm membrane, and confocal fluorescence images showed that a massive afflux occurred after cell death. ${ }^{36}$ The reduction of the number of bacteria mediated by PDT in a burn wound was rapid (less than one hour) compared to standard therapy (silver sulfadiazine cream) which required several days to complete treatment. Cell segmentation by the PPs prevented recolonization and had a protective effect on the tissues. ${ }^{37}$

The present use of PDT with AICIPC and MB was found to be safe for the dura mater and did not cause significant neurotoxic changes. Its application to the treatment of extradural disease could be a highly useful tool and a field to be explored. The limitations of the present study were the absence of comparative studies in the literature, the large number of photosensitizers and laser types with similar characteristics, and the small number of animals used. Immunohistochemistry and electron microscopy studies will be necessary for more detailed experiments in order to obtain a more in-depth analysis of the interaction of PDT and photosensitizers on the dura mater and neural tissue.

\section{CONCLUSION}

Neurological and histopathological assessment showed that PDT with AICIPc and MB does not cause neurotoxicity when applied to the dura mater of Wistar rats. Based on these observations, we conclude that PDT, AICIPC and MB offer excellent perspectives for use in further clinical trials.

All authors declare no potential conflict of interest related to this article.

CONTRIBUTION OF THE AUTHORS: Each author made significant individual contributions to this manuscript. Study concept and design: HRTC (0000-0003-3965-6886)*, LAL (0000-0002-5873-2656)* and HLAD (0000-0003-4274-0130)*. Experimental procedures and data collection: HRTC, EADBB $(0000-0002-4158-7376)^{\star}$, FLP $(0000-0001-6293-4157)^{\star}$ and CAS (0000-0001-7306-0715)*. Data interpretation and analysis: HRTC, FLP, CAS and ACT (0000-0003-4198-9321)*. Development of the article: HRTC, LAL, LMZ (0000-0001-6955-2557)*. Critical review of the article: ACT and HLAD. Review of the final version for submission: LAL and HLAD. *ORCID (Open Researcher and Contributor ID).

\section{REFERENCES}

1. Portilho FA, Cavalcanti CE, Miranda-Vilela AL, Estevanato LL, Longo JP, et al. Antitumor activity of photodynamic therapy performed with nanospheres containing zinc-phthalocyanine. $J$ Nanobiotechnology. 2013; 11(1):41.

2. Primo FL, de Paula LB, de Siqueira-Moura MP, Tedesco AC. Photobiostimulation on wound healing treatment by CIAIPC-nanoemulsion from a multiple wavelength portable light source on a 3D-human stem cell dermal equivalent. Curr Med Chem. 2012;19(30): 5157-63.

3. Passos SK, de Souza PE, Soares PK, Eid DR, Primo FL, Tedesco ZG, et al. Quantitative approach to skin field cancerization using a nanoencapsulated photodynamic therapy agent: a pilot study. Clin Cosmet Investig Dermatol. 2013; 6: 51-9.

4. Bicalho LS, Longo JP, Cavalcanti CE, Simioni AR, Bocca AL, Santos Mde F, et al. Photodynamic therapy leads to complete remission of tongue tumors and inhibits metastases to regional lymph nodes. J Biomed Nanotechnol. 2013;9(5): 811-8.

5. Agostinis P, Berg K, Cengel KA, Foster TH, Girotti AW,Gollnick SO, et al. Photodynamic therapy of cancer: an update. CA Cancer J Clin. 2011;61(4): 250-81.

6. Allison RR, Downie GH, Cuenca R, Hu XH, Childs CJ, Sibata CH. Photosensitizers in clinical PDT. Photodiagnosis Photodyn Ther. 2004; 1(1): 27-42.

7. Kübler AC.Photodynamic therapy. Med Laser Appl. 2005; 20(1):37-45.

8. Castaño AP, Demidova TN, Hamblin MR. Mechanisms in photodynamic therapy: part: twocellular signaling, cell metabolism and models of cell death. Photodiagnosis Photodyn Ther 2005; 2(1): 1-23.

9. Deminova TN, Hamblin MR: Effect of cell-photosensitizer binding and cell density on microbial photoinactivation. Antimicrob Agents Chemother. 2005; 49(6): 2329-35 
10. Allison RR, Downie GH, Cuenca R, Hu XH, Childs CJ, Sibata CH. Photosensitizers in clinical PDT. Photodiagn Photodyn Ther. 2004; 1(1):27-42.

11. Mensudar R: Photodynamic therapy: a review. World J Medical Sciences. 2014; 10(2): 139-142.

12. Nunes SM, Sguilla FS, Tedesco AC. Photophysical studies of zinc phthalocyanine and chloroaluminum phthalocyanine incorporated into liposomes in the presence of additives. Braz $\mathrm{J}$ Med Biol Res. 2004;37(2): 273-84

13. Longo JP, Lozzi SP, Simioni AR, Morais PC, Tedesco AC, Azevedo RB. Photodynamic therapy with aluminum-chloro-phthalocyanine induces necrosis and vascular damage in mice tongue tumors. J Photochem Photobiol B. 2009; 94(2):143-6.

14. Rocha MS, Lucci CM, Longo JP, Galera PD, Simioni AR, Lacava ZG, et al. Aluminum-chloride-phthalocyanine encapsulate in liposomes: activity against naturally occurring dog breast câncer cells. J Biomed Nanotechnol. 2012; 8(2):251-7.

15. Barbugli PA, Siqueira-Moura MP, Espreafico EM, Tedesco AC. In vitro phototoxicity of liposomes and nanocapsules containing chloroaluminum phthalocyanine on hyman melanoma cell line. J Nanosci Nanotechnol. 2010:10(1): 569-73.

16. Brancaleon L, Moseley $\mathrm{H}$. Laser and non-laser light sources for photodynamic therapy. Lasers Med Sci. 2002; 17(3):173-86.

17. Rodrigues GB, Primo FL, Tedesco AC, Braga GU. In vitro photodynamic inactivation of Cryptococcus neoformans melanized cells with chloroaluminum phthalocyanine nanoemulsion. Photochem Photobiol. 2012; 88(2): 440-7.

18. Mason TG, Graves SM, Wilking JN, Lin MY. Extreme emulsification: Formation and structure of nanoemulsions. Condens Matter Phys. 2006; 9(1): 193-9.

19. Solans C, Izquierdo PJ, Nolla J, Azemar N, Garcia-Celma MJ. Nano- emulsions. Curr Opin Colloid Interface Sci. 2005; 10(3-4): 102-10

20. Basso DM, Beattir MS, Bresnahan JC. A sensitive and reliable locomotor rating scale for open field test in rats. J Neurotrauma. 1995;12(1): 1-21.

21. Behmer OA, Tolosa EMC, Rodrigues CJ, Freitas Neto A. Manual de técnicas para histologia normal e patológica. São Paulo: Manole. 2003

22. Vural K, Tuğlu MI: Neurotoxic effect of statins on mouse neuroblastoma NB2a cell line. Eur Rev Med Pharmacol Sci. 2011:15(9): 985-91.

23. Demidova TN, Hamblin MR. Photodynamic therapy targeted to pathogens. Int J Immunopathol Pharmacol. 2004; 17(3): 245-54.

24. Bockstahler LE, Lytle CD, Hellman KB. A review of photodynamic therapy for herpes simplex: benefits and potential risks. N Y J Dent. 1975; 45(5): 148-57.
25. Kostron H. Photodynamic diagnosis and therapy and the brain. Methods Mol Biol. 2010; 635: 261-80.

26. Muragaki Y, Akimoto J, Maruyama T, Iseki H, Ikuta S, Nitta M, et al. Phase II clinical study on intraoperative photodynamic therapy with talaporfin sodium and semiconductor laser in patients with malignant brain tumors. J Neurosurg. 2013;119(4): 845-52.

27. Myers MG, Oxman MN, Clark JE, Arndt KA. Failure of neutral-red photodynamic inactivation in recurrent herpes simplex virus infections. N Engl J Med. 1975; 293(19): 945-9.

28. Abdel-Hady ES, Martin-Hirsch P, Duggan-Keen M, Stern PL, Moore JV, Corbitt G, et al. Immunological and viral factors associated with the response of vulval intraepithelial neoplasia to photodynamic therapy. Cancer Res. 2001; 61(1): 192-6.

29. Miki Y, Akimoto J, Yokoyama S, Homma T, Tsutsumi M, Haraoka J, et al. Photodynamic therapy in combination with taloporfin sodium induces mitochondrial apoptotic cell death accompanied by necrosis in glioma cells. Biol Pharm Bull. 2013; 36(2): 215-21.

30. Szeimies RM, Landthaler M, Karrer S. Non-oncologic indications for ALA-PDT. J Dermatol Treat. 2002; 13(Suppl1): S13-8.

31. Allen CM, Langlois R, Sharman WM, La Madeleine CL, Van Lier JE. Photodynamic properties of amphiphilic derivates of aluminum tetrasulfophthalocyanine. Photochem. 2002; 76(2): 208-16.

32. Durmus M, Nyokong T. Photophysicochemical and fluorescence quenching studies of benzyloxyphenoxy-substituted zinc phthalocyanines. Spectrochim Acta A Mol Biomol Spectr. 2008;69(4): 1170-7

33. Sadzuka Y, Iwasaki F, Sugiyama I, Horiuchi K, Hirano T, Ozawa H, et al. Study on liposomalization of zinc-coproporphyrin I as a novel drug in photodynamic therapy. Int J Pharm. 2007; 338(1-2): 306-9.

34. Proffitt RT, Williams LE, Presant CA, Tin GW, Uliana JA, Gamble RC, et al. Tumor-imaging potential of liposomes loaded with IN-111-NTA - biodistribution in mice. J Nucl Med. 1983; 24(1): 45-51.

35. Li Q, Liu Y, Li W, Feng S. Photodynamic therapy as a potential treatment for spinal cord injury. Med Hypotheses. 2011; 77(1): 58-9.

36. Lambrechts SA, Aalder MC, Van Marle J. Mechanistic study of the photodynamic inactivation of Candida albicans by a cationic porphyrin. Antimicrob Agents Chemother. 2005:49(5): 2026-34.

37. Lambrechts AS, Deminova TN, Aalders MC, Hasan T, Hamblin MR. Photodynamic therapy for Staphylococcus aureus infected burn wounds in mice. Photochem Photobiol Sci. 2005; 4(7): 503-9. 